\title{
Ammoniacal Carbonate Leaching: Effect of Dissolved Sulfur in the Distillation Operation
}

\author{
Armando Rojas Vargas, ${ }^{1,2,}{ }^{*}$ María Elena Trujillo Nieves ${ }^{3}$ \\ and Yudith González Diaz ${ }^{4}{ }^{*}$ \\ ${ }^{1}$ Empresa de Servicios Técnicos de Computación, Comunicaciones y Electrónica "Rafael Fausto Orejón Forment", \\ Holguín, Cuba. \\ ${ }^{2}$ Universidad de Holguín “Oscar Lucero Moya”, Holguín, Cuba. \\ ${ }^{3}$ Centro de Investigaciones del Níquel "Alberto Fernández Monte de Oca", Holguín, Cuba. \\ ${ }^{4}$ Universidad de Oriente, Faculty of Chemical Engineering, Santiago de Cuba, Cuba \\ *Corresponding author: E-mail: arojas@eros.moa.minem.cu) \\ Tel: +53-24-51-6695
}

Received: 07-03-2020

\begin{abstract}
The distillation process in the Ammoniacal Carbonate Leaching technology was studied at bench-scale and on industrial scale. The dissolved sulfur effect in the Product-liquor that feeds to the columns, on the Basic Nickel Carbonate (BNC) properties and the operation expenses was determined. When increasing the sulfur in the liquor, we augment the selectivity towards the sulfate formation in the BNC molecule; therefore the energy consumption to the BNC thermal decomposition in the calcination process increases. Also, the nickel dissolved in the columns effluent increases due to complex reaction with $\left[\mathrm{SO}_{4}{ }^{2-}\right]$ and $\left[\mathrm{S}_{2} \mathrm{O}_{3}{ }^{2-}\right]$ ions, thus the expenses for consumption precipitation reagent increase too. Feeding carbonated liquor in the range $1.60 \leq \mathrm{NH}_{3} / \mathrm{CO}_{2}<1.80$ and $\mathrm{CO}_{2}$-rich solution increases the $\mathrm{CO}_{2}$ in the $\mathrm{BNC}$ with decreasing in sulfate; then, the mean diameter particle increases, the filtration resistance and the cake moisture diminish, which augments the productivity and reduces the energy consumption in the process of filtration and calcination. Keeping a $\mathrm{pH}$ between 8.4 and 8.7 in the columns outlet the greatest economic benefit is obtained of $0,125\left(\$ \cdot \mathrm{h}^{-1}\right)$ per $\left(\mathrm{m}^{3} \cdot \mathrm{h}^{-1}\right)$ of Product-liquor.
\end{abstract}

Keywords: Basic Nickel Carbonate; steam-stripped columns; sulfur, leaching

\section{Introduction}

The ammoniacal carbonate leaching technology for the selective extraction of nickel and cobalt from lateritic ores began operations in the mid 1940's in Cuba, in the Nicaro nickel plant. The process was originally described by M. H. Caron in 1924 and combines both hydro- and pyrometallurgy processes, it consists of the following main stages (see Fig. 1):

The lateritic ore is crushed and dried to reduce moisture from approximately $35 \%$ to $5 \%$ with combustion gases in a rotary dryer. The dried laterites are ground to size of $83 \%$ or more of the $-0.074 \mathrm{~mm}$ class, before being reduction-roasting, into Herreshoff multiple-hearth furnaces. The additive fuel oil is fed in the mineral weighing system to enable high temperature inside the furnace through its partial combustion and provide the reducing agent for the reduction process, Eqs. (1), (2).

$$
\begin{aligned}
& 2(\mathrm{Ni}, \mathrm{CO}) \mathrm{O}_{(s)}+\left(\mathrm{CO}+\mathrm{H}_{2}\right)_{(g)} \rightarrow 2 \mathrm{Ni}_{(s)}+2 \mathrm{Co}_{(s)}+\mathrm{CO}_{2(g)}+\mathrm{HI}_{2} \mathrm{O}_{(g)} \\
& 2 \mathrm{Fe}_{2} \mathrm{O}_{3(s)}+3\left(\mathrm{CO}+\mathrm{H}_{2}\right)_{(g)} \rightarrow 4 \mathrm{Fe}_{(s)}+3 \mathrm{CO}_{2(g)}+3 \mathrm{H}_{2} \mathrm{O}_{(g)}
\end{aligned}
$$

The reduced ore cooled under neutral atmosphere below $250{ }^{\circ} \mathrm{C}$ is subsequently mixed with ammonia carbonate solution, and the resulting slurry is leached in aerated tanks, flow model perfect mixed. In this process, the nickel is selectively leached from the roast product, as described the following simplified reaction, Eq. (3): ${ }^{1}$ 


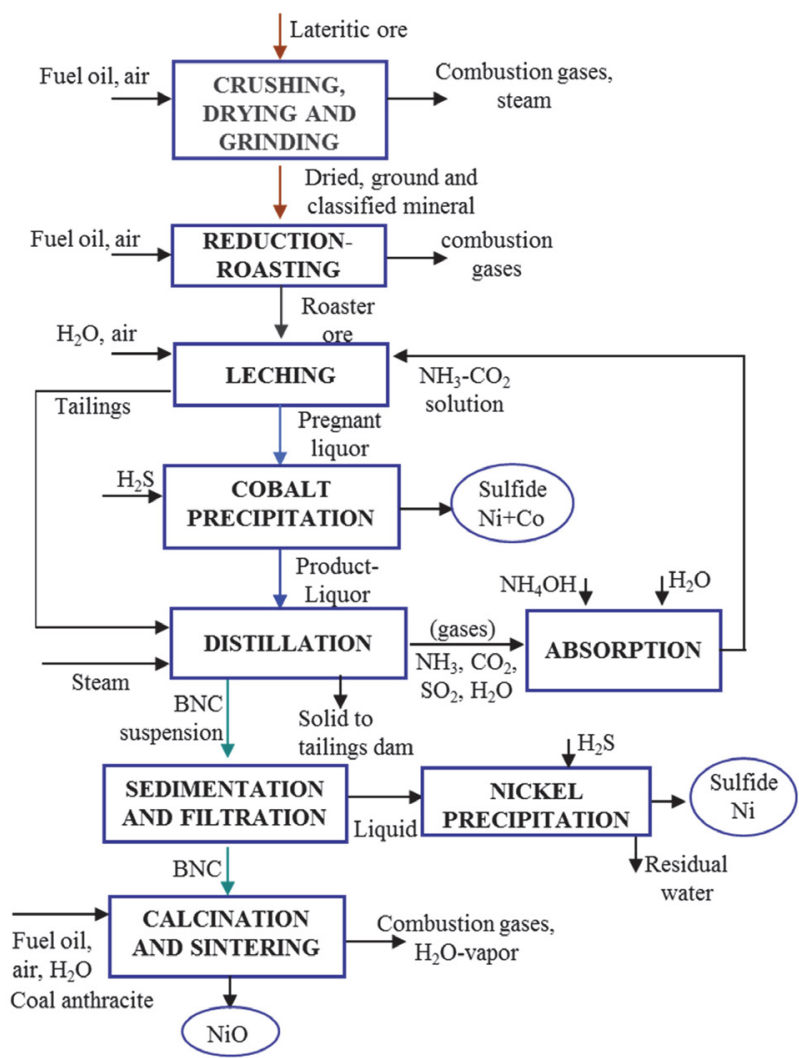

Figure 1. Process flowsheet of the nickel and cobalt producer plant in Nicaro

$$
\begin{aligned}
& \mathrm{Ni}_{(s)}+1 / 2 \mathrm{O}_{2(\mathrm{~g})}+4 \mathrm{NH}_{3(a c)}+\left(\mathrm{NH}_{4}\right)_{2} \mathrm{CO}_{3(a c)} \rightarrow \\
& \rightarrow \mathrm{Ni}\left(\mathrm{NH}_{3}\right)_{6}^{2+}+\mathrm{CO}_{3}^{2-}+\mathrm{H}_{2} \mathrm{O}
\end{aligned}
$$

Iron, cobalt and sulfur also are dissolved in leaching process. The Fe metal complex is unstable and precipitates as iron hydroxide. The sulfur remainder in the roast product, coming from the fuel oil, is oxidized to thiosulfate $\left[\mathrm{S}_{2} \mathrm{O}_{3}{ }^{2-}\right]$, polythionates $\left(\mathrm{S}_{\mathrm{n}} \mathrm{O}_{\mathrm{m}}{ }^{2-}, 2<\mathrm{n}<6\right)$, sulfite $\left[\mathrm{SO}_{3}{ }^{2-}\right]$, sulfate $\left[\mathrm{SO}_{4}{ }^{2-}\right]$ y sulphamate $\left[\mathrm{SO}_{3} \mathrm{NH}_{2}{ }^{-}\right]$, Eq. (4).

$$
\begin{aligned}
& \mathrm{S}^{2-} \rightarrow \mathrm{S}^{0} \rightarrow \mathrm{S}_{2} \mathrm{O}_{3}^{2-} \leftrightarrow \mathrm{S}_{4} \mathrm{O}_{6}^{2-} \rightarrow \\
& \rightarrow \mathrm{S}_{3} \mathrm{O}_{6}^{2-} \rightarrow \mathrm{SO}_{3}^{2-} \rightarrow \mathrm{SO}_{4}^{2-}+\mathrm{SO}_{3} \mathrm{NH}_{2}^{-}
\end{aligned}
$$

The pregnant liquor is then separated from the undissolved solid in settler tank and later Cobalt is removed from the liquor by chemistry precipitation in a tubular reactor. Then, the Product-liquor is fed in the steam-stripped columns, descends by gravity and it is brought into direct contact and counter flow with the superheated steam in multiple bubble cap trays. The volatiles compounds $\mathrm{NH}_{3}$, $\mathrm{CO}_{2}$ and $\mathrm{SO}_{2}$ evaporate, ascend and are separated by the top of the column; in turn, the Basic Nickel Carbonate (BNC) precipitates and it is obtained by the bottom in a suspension of concentration between $2,5 \%$ and $4,0 \%$ by weight, temperature of $80^{\circ} \mathrm{C}$ to $90^{\circ} \mathrm{C}$ and dissolved chem- ical species in the proportions $1.5<\mathrm{NH}_{3} / \mathrm{CO}_{2}<2.0 ; 1.8<$ $\mathrm{Ni} / \mathrm{S}<3.2 ; 10.4<\mathrm{CO}_{2} / \mathrm{S}<13.8$ and $\mathrm{pH}$ of 7.4 to 9.0 , Eqs. (5), (6). ${ }^{2}$

$$
\begin{aligned}
& 5 \mathrm{Ni}\left(\mathrm{NH}_{3}\right)_{6}^{2+}+5 \mathrm{CO}_{3}^{2-}+7 \mathrm{H}_{2} \mathrm{O} \rightarrow \\
& \rightarrow 2 \mathrm{NiCO}_{3} \cdot 3 \mathrm{Ni}(\mathrm{OH})_{2} \cdot 4 \mathrm{H}_{2} \mathrm{O}_{(\mathrm{s})}+3 \mathrm{CO}_{2(\mathrm{~g})}+30 \mathrm{NH}_{3(\mathrm{~g})} \\
& 6 \mathrm{Ni}\left(\mathrm{NH}_{3}\right)_{5}^{2+}+5 \mathrm{CO}_{3}^{2-}+\mathrm{SO}_{4}^{2-}+3 \mathrm{H}_{2} \mathrm{O} \rightarrow \\
& \rightarrow 2 \mathrm{NiCO}_{3} \cdot 3 \mathrm{Ni}(\mathrm{OH})_{2} \cdot \mathrm{NiSO}_{4(s)}+3 \mathrm{CO}_{2(\mathrm{~g})}+36 \mathrm{NH}_{3(\mathrm{~g})}
\end{aligned}
$$

The BNC is separated from the liquid in a settler tank and afterward, by filtering process. Nickel dissolved remainder in the liquid is precipitated in a tubular reactor by chemistry reaction with $\mathrm{H}_{2} \mathrm{~S}$, but $\mathrm{NH}_{3}$ constitutes a loss affecting the operating expenses.

The BNC is subsequently processed in a rotary kiln operated under slightly reducing atmosphere conditions, and it is calcined at maximum temperatures between 1000 and $1200^{\circ} \mathrm{C}$, Eq. (7).

$$
\begin{aligned}
& 2 \mathrm{Ni}(\mathrm{OH})_{2} \cdot 3 \mathrm{NiCO}_{3} \cdot \mathrm{NiSO}_{4} \rightarrow \\
& \rightarrow 6 \mathrm{NiO}(s)+3 \mathrm{CO}_{2(g)}+\mathrm{SO}_{2(g)}+2 \mathrm{H}_{2} \mathrm{O}_{(g)}+1 / 2 \mathrm{O}_{2(g)}
\end{aligned}
$$

Calcination process consists in four stages of BNC decomposition to $\mathrm{NiO}$. The first stage is the removal of physically entrained water, which represents between the $45 \%$ and $55 \%$ of heat supplied to the kiln, ${ }^{3,4}$ on the other hand, the last stage belong to sulfate decomposition and require activation energy higher than the rest of the stages, of $324.4(+/-23.8) \mathrm{kJ} \cdot \mathrm{mol}^{-1}, 5$ researchers suggested that high reduction temperature of $900^{\circ} \mathrm{C}$ substantially diminishes the sulfur content, ${ }^{6}$ so the $\mathrm{BNC}$ must have the minimum humidity before being fed to the process and the lower sulfur concentration to reduce the energy consumption. Besides, during BNC decomposition, the surface segregation of sulfur, among other phenomena that occur simultaneously such as recrystallization and agglomeration, contribute to the change the chemical-physical properties of the particles, affecting the $\mathrm{NiO}$ final microstructure.

Finally, the mixture of $\mathrm{NiO}$ and anthracite coal is fed to the sintering process and a product with $93 \% \mathrm{Ni}, 0.060 \%$ $\mathrm{S}$ and size $40 \%(+2 \mathrm{~mm})$ is obtained.

This work focuses on the process of Product-liquor distillation and obtaining the Basic Nickel Carbonate. Several studies have been carried out with the purpose of reducing the concentration of nickel and ammonia in the liquid effluents of the distillation columns, also to improve the chemical-physical properties of BNC, as well as to diminish the operating expenses.

A complementary operating norm was proposed to control the thermal profile of the columns, which consists of measuring the $\mathrm{pH}$ of the $\mathrm{BNC}$ suspension at the bottom outlet of the columns and adopting the necessary corrective actions. The study was carried out on a bench-scale and industrial-scale, at the nickel producing plants in Nicaro and Punta-Gorda, Cuba. The recommended $\mathrm{pH}$ range 
was between 8.3 and 8.7, it was obtained by optimizing the convenience function at a minimum expense due to ammonia losses and consumption of dissolved nickel precipitation reagent. If $\mathrm{pH}>8.7$, the Product-liquor distillation is characterized by low thermal profile, the concentration of dissolved $\mathrm{NH}_{3}$ and $\mathrm{Ni}$ is high, therefore the operation expenses increases in relation to the recommended range (sub-distillation conditions). If $\mathrm{pH}<8.3$, so the thermal profile is high, the nickel is leached from BNC increasing the $\mathrm{Ni}$ cation in solution, thus the operation expenses increases although the $\mathrm{NH}_{3}$ concentration continuous lowering (over-distillation conditions). The convenience function was based on the second-order polynomial function between $\mathrm{Ni}$ vs. $\mathrm{pH}$, and the potential function between $\mathrm{NH}_{3}$ vs. $\mathrm{pH}^{2,8,9}$

Based on the principles of simultaneous equilibrium and mass balance, a series of thermodynamic equations of $\mathrm{Ni}(\mathrm{II})-\mathrm{NH}_{3}-\mathrm{CO}_{3}-\mathrm{H}_{2} \mathrm{O}$ systems at $25^{\circ} \mathrm{C}$ were deduced and thermodynamic diagrams of $\log [\mathrm{Ni}]$ versus $\mathrm{pH}$ at different solution compositions were drawn, to explain the mechanism of precipitation particles with different microscopic shapes. When de $\mathrm{pH}$ is above 7.0 , the precipitation proceeds slowly and leads to the formation of dense spherical particles. Between pH 6 to 8, the nickel concentration in the solution goes down with $\mathrm{pH}$ to a minimum point, then goes up to a maximum point following a parabolic function, when concentration of $\left[\mathrm{CO}_{3}{ }^{2-}\right]$ increases, more nickel ions precipitate as the solid particle which leads to decrease of nickel in the solution. $\left[\mathrm{Ni}^{2+}\right]$ cation gradually increase with increasing $\left[\mathrm{NH}_{3}\right]$ by the formation of nickel ammine-complexes, $\mathrm{Ni}\left(\mathrm{NH}_{3}\right)_{\mathrm{n}}{ }^{2+},(\mathrm{n}=1-6)$. The higher the concentration of ammonia is, the higher $\left[\mathrm{Ni}^{2+}\right]$ in the solution are. ${ }^{10}$ For the system $\mathrm{Ni}(\mathrm{II})-\mathrm{NH}_{3}-\mathrm{CO}_{2}-\mathrm{SO}_{2}-\mathrm{H}_{2} \mathrm{O}$ these diagrams were drawn simulating the concentration of the ionic species at the bottom outlet of the columns, $\left[\mathrm{Ni}^{2+}\right]$ cation increase with increasing $\left[\mathrm{SO}_{4}{ }^{2-}\right]$ and $\left[\mathrm{S}_{2} \mathrm{O}_{3}{ }^{2-}\right]$ ions concentration because of complex reactions. As the sulfur concentration increases, the minimum point of nickel concentration shift towards a more alkaline $\mathrm{pH} .{ }^{2}$ Nis dependence on $\mathrm{pH}$ in both studies was similar to the results obtained experimentally in the distillation columns for 6.0 $\leq \mathrm{pH} \leq 8.0$.

From experimental measurements in the distillation process at the nickel producing plants in Nicaro and Punta-Gorda, a statistical model was obtained by Multiple Linear Regression, for the nickel dissolved estimate, in function of the concentration of $[\mathrm{S}],\left[\mathrm{NH}_{3}\right]$ and $\left[\mathrm{CO}_{2}\right]$ in the Product-liquor that feeds the distillation columns and the $\mathrm{pH}$ in the BNC suspension. The evaluation of the model indicated that when operating with a high $\mathrm{Ni} / \mathrm{S}$ ratio $(\mathrm{Ni} / \mathrm{S}$ $\geq 1.8)$ and a correct carbonation $\left(1.60 \leq \mathrm{NH}_{3} / \mathrm{CO}_{2} \leq 1.75\right)$, in the suspension of BNC at the column outlet, a lower concentration of dissolved nickel is obtained and therefore the consumption of reagents for the chemical precipitation diminish resulting in lower expenses. ${ }^{2}$ This was explained because it increases the selectivity towards the carbonate formation in the BNC molecule, while decreases the sulfate formation; however, no experimental results have been presented that show these changes in the chemical composition of BNC.

The effect of carbon dioxide dissolved in the Product-liqueur over the $\mathrm{BNC}$ characteristic was represented in pseudo-equilibrium diagram, $\log \left[\mathrm{NH}_{3}\right]$ versus $\log \left[\mathrm{CO}_{3}{ }^{2-}\right]$, for the $\mathrm{Ni}-\mathrm{NH}_{3}-\mathrm{CO}_{3}{ }^{2-}-\mathrm{H}_{2} \mathrm{O}$ system at $100{ }^{\circ} \mathrm{C}$, Eh $0.5 \mathrm{~V}, \mathrm{Ni}$ $0.001 \mathrm{M}, \mathrm{pH}$ 6.75. This diagram indicated that the $\mathrm{CO}_{2}$ concentration should be controlled in the liquor, to avoid the nickel hydroxide precipitation. The formation of hydroxylated products is undesirable, since their drying and dissolution properties are lower than that of Basic Nickel Carbonate. ${ }^{11}$ For the $\mathrm{Ni}(\mathrm{II})-\mathrm{NH}_{3}-\mathrm{SO}_{4}-\mathrm{H}_{2} \mathrm{O}$ systems, the speciation of nickel in ammonia solution has been examined by distribution-pH diagrams, $1 \mathrm{M}\left(\mathrm{NH}_{4}\right)_{2} \mathrm{SO}_{4}$ solution, $0.01 \mathrm{M} \mathrm{Ni}^{2+}$. In the region between $\mathrm{pH} 1.5$ and $\mathrm{pH} 8$ the predominant nickel species is a soluble, negatively charged sulfate complex [ $\left.\mathrm{Ni}\left(\mathrm{SO}_{4}\right)_{2}{ }^{2-}\right]$, in the region from $\mathrm{pH} 8$ to $\mathrm{pH} 12$, there is a series of nickel ammine-complexes with successively increasing number of incorporated ammonia ligands, $\mathrm{Ni}\left(\mathrm{NH}_{3}\right)_{\mathrm{n}}{ }^{2+}$, $(\mathrm{n}=1-6)$. In $0.05 \mathrm{M} \mathrm{Ni}^{2+}$ solution, nickel hydroxyl-sulfate precipitates in the region around $\mathrm{pH} 8,{ }^{12}$ which suggests that at $\mathrm{pH}<8.3$ (according to the operating norm by $\mathrm{pH}$ ), the nickel leaching from BNC may be particularly associated with the presence of sulfate in the BNC molecule, what is accentuated to conditions of low carbonation of the Product-liqueur. It should be highlighted that in more diluted aqueous solution of nickel(II) sulfate, $10^{-3} \mathrm{M}$, the ions $\left[\mathrm{Ni}_{2}\left(\mathrm{SO}_{4}\right)\left(\mathrm{H}_{2} \mathrm{O}\right)_{\mathrm{n}}\right]^{2+}$ and $\left[\mathrm{Ni}_{\mathrm{m}}\left(\mathrm{SO}_{4}\right)_{\mathrm{m}-1}\left(\mathrm{H}_{2} \mathrm{O}\right)_{\mathrm{n}}\right]^{2+}(\mathrm{m} \approx 6, \mathrm{n} \approx 12)$ have been identified, also, at $5 \cdot 10^{-4} \mathrm{M}$, triple ion $\left[\mathrm{Ni}\left(\mathrm{SO}_{4}\right)_{2}\right]^{2-}$, nickel cluster $\left[\mathrm{Ni}_{2}\left(\mathrm{SO}_{4}\right)_{3}\right]^{2-}, \quad\left[\mathrm{Ni}_{5}\left(\mathrm{SO}_{4}\right)_{6}\right]^{2-}$ and higher-mass ions $\left[\mathrm{Ni}_{3}\left(\mathrm{SO}_{4}\right)_{2}\left(\mathrm{H}_{2} \mathrm{O}\right)_{\mathrm{n}}\right]^{2+}(0 \leq \mathrm{n} \leq 2) .{ }^{13}$

Few investigations on Basic Nickel Carbonate have considered the presence of sulfur in the molecule. Structures such as: $2 \mathrm{NiCO}_{3} \cdot 3 \mathrm{Ni}(\mathrm{OH})_{2} \cdot 4 \mathrm{H}_{2} \mathrm{O}, \mathrm{NiCO}_{3} \cdot 2 \mathrm{Ni}(\mathrm{OH})_{2}$ . $4 \mathrm{H}_{2} \mathrm{O}$ and $\mathrm{NiCO}_{3} \cdot \mathrm{Ni}(\mathrm{OH})_{2} \cdot 2 \mathrm{H}_{2} \mathrm{O}$ are reported, the particles are spherical and ellipsoidal in shape, ranging from 0.4 to $23 \mu \mathrm{m}$ in diameter. The $\mathrm{BNC}$ dried at $105^{\circ} \mathrm{C}$ contained approximately $52 \%$ wt $\mathrm{Ni}, 12.9 \%$ wt $\mathrm{CO}_{2}$ and $0.001 \%$ wt $\mathrm{S}^{7}$ On the other hand, considering sulfur, the general structure $\left(\mathrm{NiCO}_{3}\right)_{\mathrm{x}} \cdot\left(\mathrm{Ni}(\mathrm{OH})_{2}\right)_{\mathrm{y}} \cdot\left(\mathrm{NiSO}_{4}\right)_{\mathrm{z}} \cdot \mathrm{nH}_{2} \mathrm{O}$ is presented. ${ }^{5}$ The $\mathrm{BNC}$ dried at $60{ }^{\circ} \mathrm{C}$ contained $45.6-$ $50.0 \%$ wt $\mathrm{Ni}, 1.9-4.9 \%$ wt $\mathrm{CO}_{2}, 1.8-3,1 \%$ wt $\mathrm{S}$, real density $2.8-3.2 \mathrm{mg} \cdot \mathrm{L}^{-1}$ and $12-22 \mu \mathrm{m}$ in mean diameter of microparticles. ${ }^{3,14}$

Colloidal processing supplies great possibilities to obtain smart materials by means of manipulation of molecular structures and control of inter-particle forces. ${ }^{15} \mathrm{~A}$ colloid is a chemical system, in which one substance is microscopically dispersed evenly throughout another medium substance of a continuous phase. The behavior of colloidal particles in aqueous medium is a consequence of interaction between particles surface and liquid medium. Colloidal particle size distribution, between $10^{-3} \mu \mathrm{m}$ and 1 
$\mu \mathrm{m}$, shape, surface area, density, as well as chemical composition is related to the stabilization of the colloidal system. The properties of starting material have substantial influence on rheological properties; filtration, drying, sintering process; and in the final microstructure. ${ }^{7,14}$

The particle behaviour in suspension and its stability can be understood using electric double layer model (EDL) or DLVO theory (Derjaguin, Landau, Verwey and, Overbeek), as well as the concepts surface potential, isoelectric point and zeta potential. ${ }^{15,16}$ Stability refers to the condition in which the colloidal particles do not aggregate at a significant rate. Aqueous suspension stabilization can be controlled by the mechanisms electrostatic, steric, electrosteric and nanoparticle haloing stabilization, by the following methods: adjusting either ionic strength or $\mathrm{pH}$ of the electrolyte solution; adding a component like a surfactant or polymer that adsorbs on the colloidal particles and changes their surface properties; a polyelectrolyte that impart electrostatic and steric stabilization to a given colloidal dispersion; or highly charged nanoparticles by forming a nonadsorbing nanoparticle layer around neutral colloidal particle, which presents as an effective surface charge and produces an electrostatic repulsion that mitigates the inherent van der Waals attraction between them. ${ }^{17,18}$ A method for purifying Basic Nickel Carbonate of $\mathrm{Na}^{+}, \mathrm{Cl}^{-}$ions and other impurities on its surface was clarified by the electric double layer model and it was proposed a washing-drying-rewashing-drying process, ${ }^{19}$ but other studies have not been performed about colloidal processing or sulfur removal of $\mathrm{Ni}(\mathrm{II})-\mathrm{NH}_{3}-\mathrm{CO}_{2}-\mathrm{SO}_{2}$ $\mathrm{H}_{2} \mathrm{O}$ system.

The purpose of this work was to determine the dissolved-sulfur concentration effect in the Product-liquor, on the BNC properties, the expenses in the distillation process and determine the $\mathrm{pH}$ range for the greatest economic benefit.

\section{Materials and Methods}

The evaluation was carried out on a bench-scale and industrial-scale.

A steam-stripped mini-column was used with 200 $\mathrm{mm}$ diameter, $1320 \mathrm{~mm}$ height, 2 separating trays at the top, 8 bubble cap trays, 1 cup/trays of $106 \mathrm{~mm}$ diameter and 1 sampler/ trays, which allowed performing the concentration profile of dissolved chemical species in six inner positions along the column, (Fig. 1).

On the other hand, the industrial-scale steamstripped columns, at the Nicaro nickel plant, have $3.4 \mathrm{~m}$ in diameter, $18.0 \mathrm{~m}$ height, 18 bubble cap trays, 24 cups/trays, operating pressure at the bottom of $127.5 \mathrm{MPa}$ and samplers in the fifth tray. ${ }^{20}$

The samples were taken in the Product-liquor, in the BNC suspension at the columns outlet, and in the corresponding samplers along the columns. Also, a $\mathrm{CO}_{2}$-reach

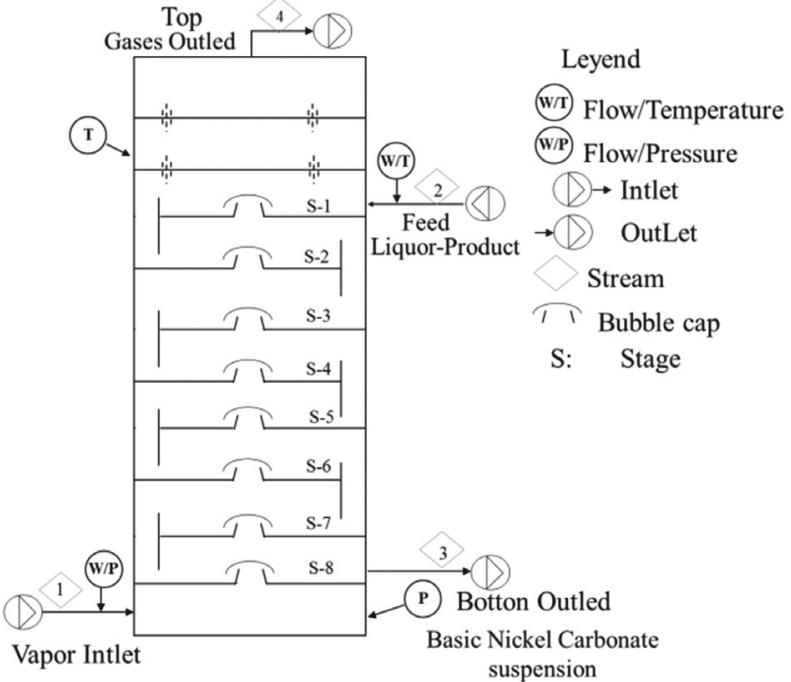

Figure 2. Steam-stripped mini-column

solution was used, which is produced in the gases absorption systems of the industrial process, with $\mathrm{NH}_{3} 130-140 \mathrm{~g}$ $\cdot \mathrm{L}^{-1}$ and $\mathrm{CO}_{2} 90-100 \mathrm{~g} \cdot \mathrm{L}^{-1}$.

The BNC suspension samples were processed as follows: the aliquot needed to determine the suspension $\mathrm{pH}$ and the dissolved compounds concentration $\left(\mathrm{g} \cdot \mathrm{L}^{-1}\right)$ $\left[\mathrm{NH}_{3}\right],\left[\mathrm{CO}_{2}\right],[\mathrm{Ni}],[\mathrm{S}],\left[\mathrm{SO}_{4}{ }^{2-}\right],\left[\mathrm{S}_{2} \mathrm{O}_{3}{ }^{2-}\right]$ was taken; the rest was filtered in a Büchner funnel connected to a sidearm flask and a vacuum pump, the $\mathrm{BNC}$ was dried at $60^{\circ} \mathrm{C}$ and it was characterized according the concentration (\%) of $[\mathrm{Ni}],[\mathrm{Co}],[\mathrm{MgO}],\left[\mathrm{CO}_{2}\right],[\mathrm{S}]$. The real and apparent BNC density was determined.

The chemical analyzes were performed applying volumetric, gravimetric, potentiometric and Atomic Absorption Spectrophotometry (AAS) methods. All the $\mathrm{pH}$ measurements were made at $25^{\circ} \mathrm{C}$, using a $\mathrm{pH}$ meter PHILIPS PW-9420115-230 V, 50-60 Hz, precision $0,001 \mathrm{pH} /{ }^{\circ} \mathrm{C}$; and for determining the size distribution, the Laser-Particle-Sizer Analysette 22.

Experimental runs were performed in three stages:

Stage 01. Bench-scale. A full-factorial design, two-level, $2^{k}$ experimental runs, $k$-factors with one center point, was carried out at the mini-column, with the aim of determining the effect of the independent variables and their domain, on the concentration of dissolved nickel and the BNC properties, also, the interaction $\mathrm{Ni}(\mathrm{II})$ and $\mathrm{NH}_{3}$ versus $\mathrm{pH}$. The independent variables (factors) were: temperature at the top: 80,85 and $90^{\circ} \mathrm{C}$, and liquor flow: 12,16 and $20 \mathrm{~L} \cdot \mathrm{h}^{-1}, 15$ experiments in total, each lasting 10 hours. Once the operation stabilized, the samples were taken in $100 \mathrm{~mL}$ plastic bottles. The Liquor Product chemical composition remained fixed, it had a $\mathrm{Ni} / \mathrm{S}$ ratio 2.66; $\mathrm{Ni} /\left[\mathrm{SO}_{4}{ }^{2-}\right] 5.08, \mathrm{Ni} /\left[\mathrm{S}_{2} \mathrm{O}_{3}{ }^{2-}\right] 3.11$ and $\mathrm{NH}_{3} / \mathrm{CO}_{2} 1.73$.

Stage 02. Bench-scale. In the mini-column, 6 experiments in total were carried out with and without feeding $\mathrm{CO}_{2}$-rich solution by a side trays of the column, at a flow of $2 \mathrm{~L} \cdot \mathrm{h}^{-1}$, with the purpose of conducting an exploratory 
study and determining the effect on the concentration of nickel dissolved and the BNC properties. The temperature at the top was $90^{\circ} \mathrm{C}$ and the Product-liquor flow of $20 \mathrm{~L}$. $\mathrm{h}^{-1}$, at the minimum nickel concentration in solution obtained in step 01. The Product-liquor chemical composition had a Ni/S ratio 3.32, $\mathrm{Ni} /\left[\mathrm{SO}_{4}{ }^{2-}\right] 6.82, \mathrm{Ni} /\left[\mathrm{S}_{2} \mathrm{O}_{3}{ }^{2-}\right]$ 4.25 and $\mathrm{NH}_{3} / \mathrm{CO}_{2}$ 1.78. The specific cake resistance and the medium resistance of filtration was determined, to a temperature of $80^{\circ} \mathrm{C}, 16 \%$ in weight of solids and constant pressure drop of $37581.75 \mathrm{~N} / \mathrm{m}^{2}$, applying the Kraft paper as membrane. ${ }^{14}$

Stage 03. Industrial-scale. The experimental runs were carried out at Nicaro nickel plant, in order to validate the results previously obtained in the mini-column, at different ionic composition of the Product-liquor. The variables Liquor flow (Qa) $56.4 \mathrm{~m}^{3} \cdot \mathrm{h}^{-1}( \pm 4.5)$, temperature at the column top (Tp) $83.0^{\circ} \mathrm{C}( \pm 1.4)$, and quotient between Liquor flow and steam flow $(\mathrm{Qa} / \mathrm{Wv}) 5.7 \mathrm{~m}^{3} \cdot \mathrm{kg}^{-1}( \pm 1.2)$ were fixed. The sampling was carried out in several periods or campaigns to guarantee the representativeness in the ionic composition of the Liquors processed in the columns, every 4 hours in $100 \mathrm{~mL}$ plastic bottles. The Product-liquor chemical composition was: $1.0 \leq \mathrm{Ni} / \mathrm{S} \leq 2.8,1.8 \leq \mathrm{Ni} /\left[\mathrm{SO}_{4}{ }^{2-}\right.$ ]$\leq 4.0,1.2 \leq \mathrm{Ni} /\left[\mathrm{S}_{2} \mathrm{O}_{3}{ }^{2-}\right] \leq 3.0,1.60 \leq \mathrm{NH}_{3} / \mathrm{CO}_{2} \leq 1.94$.

The operating variables: flow, temperature and pressure were monitored in real-time using Supervisory Control and Data Acquisition EROS (SCADA EROS) and the values were taken from the data historian.

The chemical analysis database was organized into dataset ( $\mathrm{j}=1$ to 10 ) according to the $\mathrm{Ni} / \mathrm{S}$ and $\mathrm{NH}_{3} / \mathrm{CO}_{2}$ ratio in the Product-liquor, maintaining a standard deviation approximately equal to $0.5 \mathrm{~g} \cdot \mathrm{L}^{-1}$. Only in this way was it possible to obtain the interactions of $[\mathrm{Ni}]$ and $\left[\mathrm{NH}_{3}\right]$ versus $\mathrm{pH}$, due to the concentration variation and diversity of chemical species in solution. ${ }^{2.9}$

The relative frequency distribution $\left(f_{\mathrm{j}}\right)$ in which each dataset ( $j$ ) appears was calculated from the number of samples that compose it, thus, $f_{j}$ represents the fraction of data values that fall in a dataset. In addition, frequency histograms ware constructed in each dataset, for the $\mathrm{pH}$ values in the BNC suspension in the columns outlet stream, interval class width 0.1 (classes: $\mathrm{pH}<7.7 ; 7.7 \leq \mathrm{pH}<7.8 ; . . ; 8.8 \leq \mathrm{pH}$ $<8.9 ; \mathrm{pH}>8.9$ ), the number of class intervals $(i)$ of greatest interest was $i=13(7.7 \leq \mathrm{pH} \leq 8.9)$ and the relative frequency distribution for $\mathrm{pH}\left(f_{\mathrm{i}}\right)$.

Then, for each dataset, the nickel concentration was fitted to polynomial function, and the ammonia to potential function. The best fitting was appreciated by the high coefficient of determination $\left(R^{2}\right)$, Eqs. (8), (9). ${ }^{2,8,9}$

$$
\begin{aligned}
& {[N i]=c_{1}+c_{2} \cdot p H+c_{3} \cdot p H^{2}} \\
& {\left[N H_{3}\right]=c_{4} \cdot p H^{c_{5}}}
\end{aligned}
$$

To perform the economic valuation, Eq. (10) to (13) were applied.

$$
\begin{aligned}
& Q_{l}=Q_{\mathrm{a}} \cdot\left(1+\frac{15}{100}\right) \cdot\left(1-\frac{\rho_{p}-\rho_{l}}{\rho_{s}-\rho_{l}}\right) \\
& G_{i}=Q_{l} \cdot\left\{\left[N H_{3}\right]_{i} \cdot P_{1}+\left[N i_{i}\right]_{\cdot} \cdot d \cdot P_{2}\right\} \\
& \mathrm{G}=\sum_{j=1}^{10} f_{j} \cdot G_{j}=\sum_{j=1}^{10} f_{j} \cdot \sum_{i=1}^{13} f_{i} \cdot G_{l} \\
& \mathrm{~A}=\sum_{j=1}^{10} f_{j} \cdot\left(G_{j}-\bar{G}_{i}\right)
\end{aligned}
$$

The liquor flow in the columns effluent, $Q_{1}\left(\mathrm{~m}^{3} \cdot \mathrm{h}^{-1}\right)$, was determined in function of the density, $\rho\left(\mathrm{kg} / \mathrm{m}^{3}\right)$, corresponding to the solid (s), the liquid (l) and the suspension (p), taking a flow of Product-liquor (Qa) of $1 \mathrm{~m}^{3} / \mathrm{h}$ (base) and a $15 \%$ of volume increase due to steam condensation, according to design data of the industrial installation, Eq. (10).

The operation expenses, $G_{\mathrm{i}}\left(\$ \cdot \mathrm{h}^{-1}\right)$ per $\left(\mathrm{m}^{3} \cdot \mathrm{h}^{-1}\right)$, for each class interval (i) of $\mathrm{pH}$ considered in the frequency histograms were calculated. The prognostic models of $\left[\mathrm{NH}_{3}\right]$ and $[\mathrm{Ni}]$ concentration $\left(\mathrm{g} \cdot \mathrm{L}^{-1}\right)$ as a $\mathrm{pH}$ function were used, in the interval $7.7 \leq \mathrm{pH}_{\mathrm{i}} \leq 8.9\left(\mathrm{pH}_{1}=7.7 ; \mathrm{pH}_{2}=\right.$ $\left.7,8, \ldots, \mathrm{pH}_{13}=8,9\right)$. The ammonia price $\left(\mathrm{P}_{1}\right)$ of $0,350 \$ \cdot \mathrm{kg}^{-}$ ${ }^{1}$ and of nickel precipitation reagent $\left(\mathrm{P}_{2}\right) 0,740 \$ \cdot \mathrm{kg}^{-1}$ was considered, as well as the reagent consumption dose (d) $1.33 \mathrm{~kg} \cdot \mathrm{kg}^{-1}$ of precipitated nickel, Eq. (11).

The operation global expense, $\mathrm{G}\left(\$ \cdot \mathrm{h}^{-1}\right)$ per $\left(\mathrm{m}^{3}\right.$. $\mathrm{h}^{-1}$ ) was calculated taking into consideration relative frequency distribution $\left(f_{\mathrm{j}}\right)$ and $\left(f_{\mathrm{i}}\right)$, Eq. (12).

The economic benefit, $A\left(\$ \cdot \mathrm{h}^{-1}\right)$ per $\left(\mathrm{m}^{3} \cdot \mathrm{h}^{-1}\right)$, expresses numerically the amount of money that can be saved as the result of operating the distillation columns maintaining in the BNC suspension, in the outlet stream, certain $\mathrm{pH}$ range, that minimizes the expenses due to losses of dissolved ammonia and the consumption of reagent to precipitate the remainder nickel.

To determine the economic benefit, certain $\mathrm{pH}$ range was set, and the average expense $\left(\bar{G}_{\mathrm{i}}\right)$ was calculated. The interval width of $\mathrm{pH}$ was 0.4 (classes: $7.7 \leq \mathrm{pHi} \leq 8.0 ; 7.8 \leq$ $\mathrm{pHi} \leq 8.1 ; \ldots ; 8.6 \leq \mathrm{pHi} \leq 8.9)$ and the number of class intervals equal to 13 . Then, the economic benefit $(A)$ for any range of $\mathrm{pH}$ was determined as the difference between the operating expenses in a dataset $\left(G_{\mathrm{j}}\right)$ with the average expenses $\left(\bar{G}_{\mathrm{i}}\right)$ of the fixed $\mathrm{pH}$ range, considering relative frequency distribution $\left(f_{\mathrm{j}}\right)$ to make the summation. From this calculation, the $\mathrm{pH}$ range to operate at the greatest economic benefit was determined, Eq. (13).

\section{Results and Discussion}

\section{1. pH Interaction with Dissolved Nickel and Ammonia}

The nickel and ammonia profile $\left(\mathrm{g} \cdot \mathrm{L}^{-1}\right)$ as a $\mathrm{pH}$ function at $25{ }^{\circ} \mathrm{C}$ in the in the steam-stripped mini-column are shown in Figure 3. 


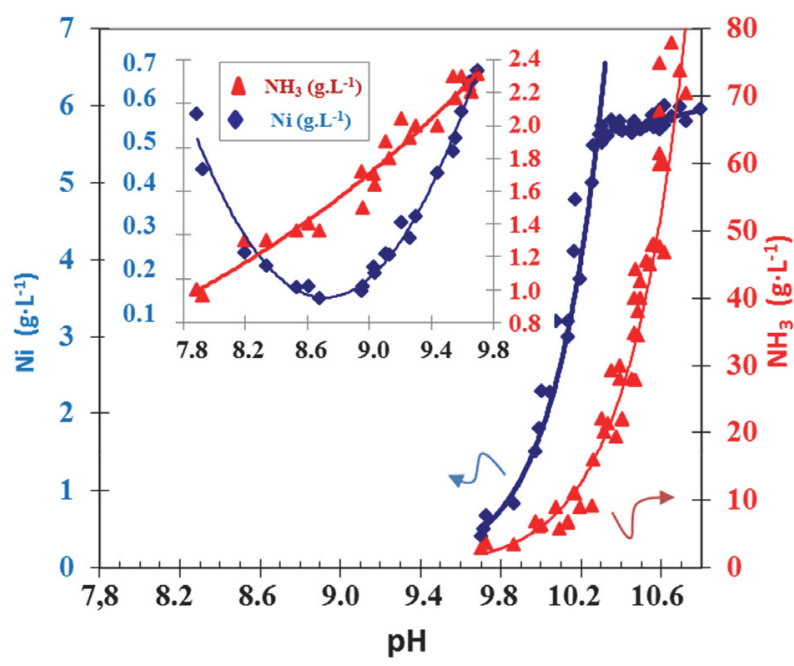

Figure 3. Profile of nickel and ammonia dissolved versus $\mathrm{pH}$ at 25 ${ }^{\circ} \mathrm{C}$ in the mini-column (Stage 01$) . \mathrm{Ni} / \mathrm{S}=2.66, \mathrm{Ni} /\left[\mathrm{SO}_{4}{ }^{2-}\right]=5.08$, $\mathrm{Ni} /\left[\mathrm{S}_{2} \mathrm{O}_{3}{ }^{2-}\right]=3.11, \mathrm{NH}_{3} / \mathrm{CO}_{2}=1.73$

The relationship between nickel and ammonia with $\mathrm{pH}$, in the trays along the mini-column, for the different levels of the factors temperature at the top and liquor flow was obtained. The alkalinity of the suspension decreased in the range of $9.7 \leq \mathrm{pH} \leq 10.7$ with the fall of ammonia concentration from $80 \mathrm{~g} \cdot \mathrm{L}^{-1}$ up to $3 \mathrm{~g} \cdot \mathrm{L}^{-1}$, following a potential function, Eq. (14).

$$
\begin{aligned}
& {\left[\mathrm{NH}_{3}\right]=2.1941 \cdot 10^{-36} \cdot p H^{36.55}} \\
& R^{2}=0.9643
\end{aligned}
$$

With regard to nickel cation, a slight descent of the concentration was appreciated due to the $\mathrm{BNC}$ precipitation, until reaching $\mathrm{pH} 10,3$ and $\left[\mathrm{NH}_{3}\right] 20 \mathrm{~g} \cdot \mathrm{L}^{-1}$; starting from this point, $\mathrm{Ni}$ (II) cation precipitated according to a potential function, Eq. (15).

$$
\begin{aligned}
& {[N i]=3.32 \cdot 10^{-42} \cdot p H^{41.73}} \\
& R^{2}=0.9696
\end{aligned}
$$

In this Figure 3, a view of the interaction between nickel and ammonia versus $\mathrm{pH}$ to $\mathrm{pH}<9.7$ is included, corresponding to low concentrations in the inferior trays of the mini-column. Nickel in solution decreased with $\mathrm{pH}$ to a minimum point, and then increased to a maximum point in the BNC suspension, following parabolic function (over-distillation), Eq. (16).

$$
\begin{aligned}
& {[N i]=0.5384 \cdot p H^{2}-9.3621 \cdot p H+40.93} \\
& R^{2}=0.9696
\end{aligned}
$$

On the other hand, form $\mathrm{pH} 9.7$ to $\mathrm{pH} 7.8$, the ammonia concentration diminished reaching concentrations as low as $1.0 \mathrm{~g} \cdot \mathrm{L}^{-1}$ following a potential function; but this could result in a leaching of nickel from the BNC molecule and an increase in the $\mathrm{Ni}$ cation in solution, Eq. (17).

$$
\begin{aligned}
& {\left[\mathrm{NH}_{3}\right]=2.05 \cdot 10^{-4} \cdot p H^{4.1082}} \\
& R^{2}=0.9610
\end{aligned}
$$

The interactions ( $\mathrm{Ni}$ vs. $\mathrm{pH}, \mathrm{NH}_{3}$ vs. $\mathrm{pH}$ ) were valid although $\mathrm{CO}_{2}$-rich solution was fed to the mini-column, as it is shown in the Figure 4. At $\mathrm{pH}$ equal to 10.33, the precipitation of the $\mathrm{BNC}$ began, with a linear decrease of nickel concentration and slope $\mathrm{m}_{1}=2.8$ (with $\mathrm{CO}_{2}$-rich solution) and $\mathrm{m}_{2}=2.3$ (without dissolution) until reaching $\mathrm{pH} 10.1$ and $\left[\mathrm{NH}_{3}\right] 15.8 \mathrm{~g} \cdot \mathrm{L}^{-1}$. From that $\mathrm{pH},\left[\mathrm{Ni}^{2+}\right]$ cation precipitated intensely according to a potential function and exponents $\mathrm{k}_{1}=39.3$ and $\mathrm{k}_{2}=36.7$ with fit quality, $R^{2}$, $95 \%$ and $97 \%$ respectively.

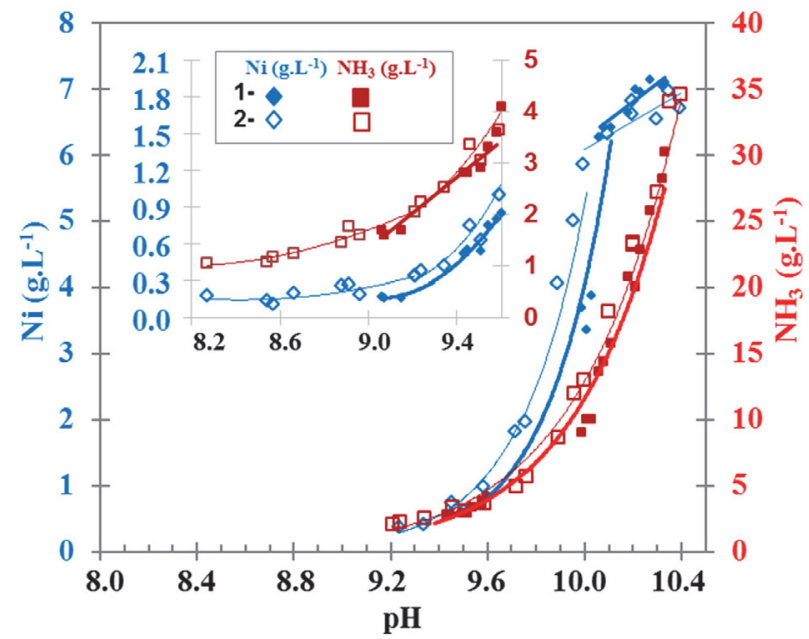

Figure 4. Profile of nickel and ammonia dissolved versus $\mathrm{pH}$ at $25^{\circ} \mathrm{C}$ in the mini-column (Stage 02). Product-liquor distillation with $^{(1-)}$ and without ${ }^{(2-)} \mathrm{CO}_{2}$-reach solution. $\mathrm{Ni} / \mathrm{S} 3.32, \mathrm{Ni} /\left[\mathrm{SO}_{4}{ }^{2-}\right] 6.82, \mathrm{Ni} /$ $\left[\mathrm{S}_{2} \mathrm{O}_{3}{ }^{2-}\right] 4.25, \mathrm{NH}_{3} / \mathrm{CO}_{2} 1.78$

From figure 4 , at $\mathrm{pH}<9.6$, corresponding to the lower trays, the concentration of both compounds decreased. For the same $\mathrm{pH}$ value, the dissolved nickel had a tendency to be slightly lower with the feeding of $\mathrm{CO}_{2}$-rich solution, than when this solution was not supplied $\left(k_{1}>k_{2}\right)$; and the ammonia concentration was similar in both experiments, keeping $90^{\circ} \mathrm{C}$ in the top of the mini-column.

On the other hand, on an industrial-scale, according to the $\mathrm{Ni} / \mathrm{S}$ and $\mathrm{NH}_{3} / \mathrm{CO}_{2}$ ratio in the Product-liquor, ten dataset were conformed, and similar interactions were obtained like these previously exposed. From Figure 5, for a liquor characterized by $\mathrm{Ni} / \mathrm{S} 1.2, \mathrm{Ni} /\left[\mathrm{SO}_{4}{ }^{2-}\right] 2.5, \mathrm{Ni} /\left[\mathrm{S}_{2} \mathrm{O}_{3}{ }^{2-}\right.$ ] 1.7 and $\mathrm{NH}_{3} / \mathrm{CO}_{2} 1.63$, at $\mathrm{pH}<9.08$ while the $\left[\mathrm{NH}_{3}\right]$ concentration decreased following a potential function $\left(R^{2}=\right.$ 96.8\%), the $\left[\mathrm{Ni}^{2+}\right]$ dissolved had a second-order polynomial tendency $\left(R^{2}=94.08 \%\right)$ and at $\mathrm{pH}<8.5$, the nickel concentration in the BNC suspension began to increase, due to the $\left[\mathrm{Ni}^{2+}\right]$ leaching of the BNC molecule (over-distillation).

These experimental results showed the possibility of controlling the distillation operation, setting a $\mathrm{pH}$ range in 


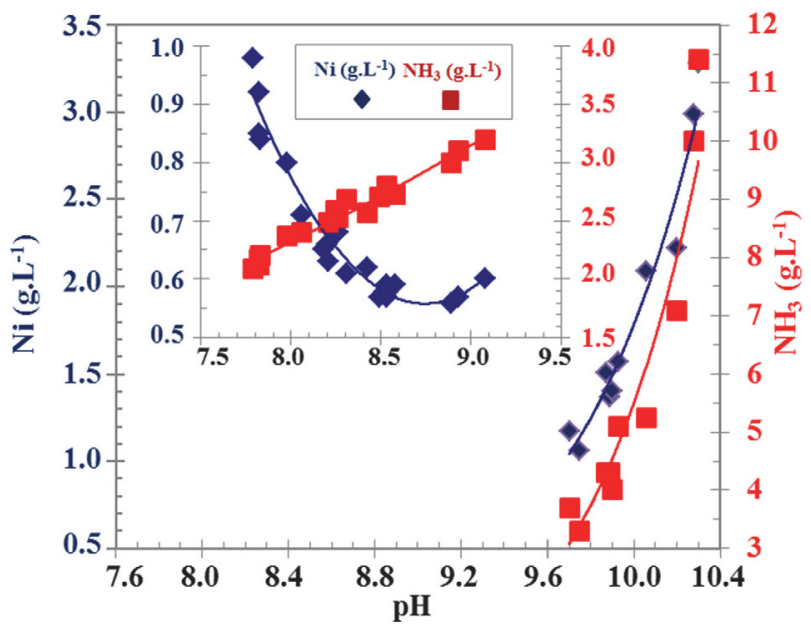

Figure 5. Profile of nickel and ammonia dissolved versus $\mathrm{pH}$ at $25^{\circ} \mathrm{C}$ in the column-industrial (Stage 03). Ni/S 1.2, Ni/[ $\left[\mathrm{SO}_{4}{ }^{2-}\right] 2.5, \mathrm{Ni} /$ $\left[\mathrm{S}_{2} \mathrm{O}_{3}{ }^{2-}\right] 1.7, \mathrm{NH}_{3} / \mathrm{CO}_{2} 1.63$.

the BNC suspension, in the outflow of the columns, at the minimum expenses due to ammonia losses and reagent consumption for the chemical precipitation of the dissolved nickel. Other similar experimental results have already been reported. ${ }^{2,8,9}$

\section{2. Effect of Sulfur on the BNC Chemical Composition}

The chemical-physical characterization of Basic Nickel Carbonate was performed, with regard to the nickel (Ni), cobalt (Co), magnesium expressed as magnesium oxide $(\mathrm{MgO})$, carbon dioxide $\left(\mathrm{CO}_{2}\right)$, sulfur $(\mathrm{S})$ concentration and the real and apparent density, the average values are shown in table 1 . The mean diameter ranged from 19 to $32 \mathrm{~mm}$.

In the mini-column, when the $\left[\mathrm{CO}_{2}\right]$ in the $\mathrm{BNC}$ increased, a tendency to decrease the $[\mathrm{S}]$ was obtained, with a second-order polynomial function and coefficient of determination, $R^{2}, 92.1 \%$, (Fig. 6). From the experimental design, the biggest concentration of $\mathrm{CO}_{2}$ in the $\mathrm{BNC}$ molecule was obtained at lowest thermal profile in the mini-column (low temperature and high flow), but the nickel dissolved at the mini-column effluent was high because of $\mathrm{pH}$ value 9.75 (+/-0.07), at sub-distillation conditions (see Fig. 3).

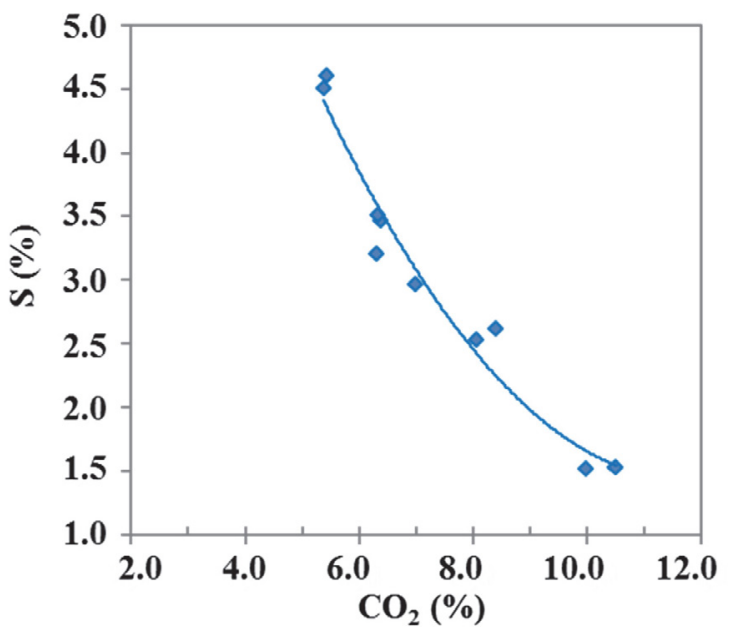

Figure 6. Interaction between sulfur and carbon dioxide in the $B a$ sic Nickel Carbonate, distillation mini-column (Stage 01).

When $\mathrm{CO}_{2}$-rich solution was fed in the steamstripped mini-column, the $\mathrm{CO}_{2}$ in the $\mathrm{BNC}$ molecule increased (table 1, Stage 02) as well as the mean diameter of particle from 24 to $32 \mathrm{~mm}$. The specific resistance presented by the filter cake diminished from 20 to $5 \cdot 10^{6} \mathrm{~m} \cdot \mathrm{kg}^{-1}$ and the membrane resistance was constant equal to 1.5 . $10^{9} \mathrm{~kg}^{-1}$; the moisture content in filter cakes decreased form $70 \%$ to $63 \%$, which benefits the subsequent process of filtration and calcination as for the productivity and energy consumption.

On the other hand, for the industrial process, the ionic composition of the Product-liquor was variable. In the period characterized by a carbonation in the range $1.60 \leq \mathrm{NH}_{3} / \mathrm{CO}_{2}<1.80$, when the $\left[\mathrm{CO}_{2}\right]$ in the BNC increased, the sulfur (S), although first it had a tendency to increase between $0.2 \%$ and $0.5 \%$, later it decreased as a second-order polynomial function, a similar result to those obtained in the mini-column, Fig. 7.

From Figure 7, it can be seen the strong dependence of the sulfur (\%) in the BNC with regard to the sulfur dissolved $\left(\mathrm{g} \cdot \mathrm{L}^{-1}\right)$ in the Product-liquor: to lower [S] dissolved and higher $\mathrm{Ni} / \mathrm{S}$ ratio, the sulfur concentration in the $\mathrm{BNC}$ was lower. However, for an $\left[\mathrm{NH}_{3} / \mathrm{CO}_{2}\right]$ ratio greater than 1.80 in the Liquor, the [S] increased with a directly proportional relationship with the $\left[\mathrm{CO}_{2}\right]$ in the BNC. Then, a correct carbonation of the Liquor, as well as feeding $\mathrm{CO}_{2}$-rich

Table 1. Characterization of Basic Nickel Carbonate

\begin{tabular}{cccccccc}
\hline $\begin{array}{c}\text { Experimental } \\
\text { stage }\end{array}$ & $\mathbf{N i}$ & $\mathbf{C o}$ & $\mathbf{M g O}$ & $\mathbf{C O}_{\mathbf{2}}$ & $\mathbf{S}$ & \multicolumn{2}{c}{$\begin{array}{c}\text { Density }\left(\mathbf{k g} / \mathbf{m}^{\mathbf{3}}\right) \\
\text { real }\end{array}$} \\
\hline $\mathbf{0 1}$ & 47.1 & 0.38 & 0.20 & 7.38 & 3.04 & 2.98 & 0.40 \\
$\mathbf{0 2}^{\mathbf{1 -}}$ & 47.8 & 0.43 & 0.09 & 9.68 & 2.39 & 2.85 & 0.46 \\
$\mathbf{0 2}^{2-}$ & 47.4 & 0.40 & 0.07 & 7.45 & 4.12 & 2.86 & 0.39 \\
$\mathbf{0 3}$ & 48.5 & 0.35 & 0.28 & 3.34 & 5.96 & 2.89 & 0.59 \\
\hline
\end{tabular}

${ }^{1-}$ Distillation of Product-liquor with $\mathrm{CO}_{2}$-rich solution ${ }^{2-}$ Distillation without this dissolution 


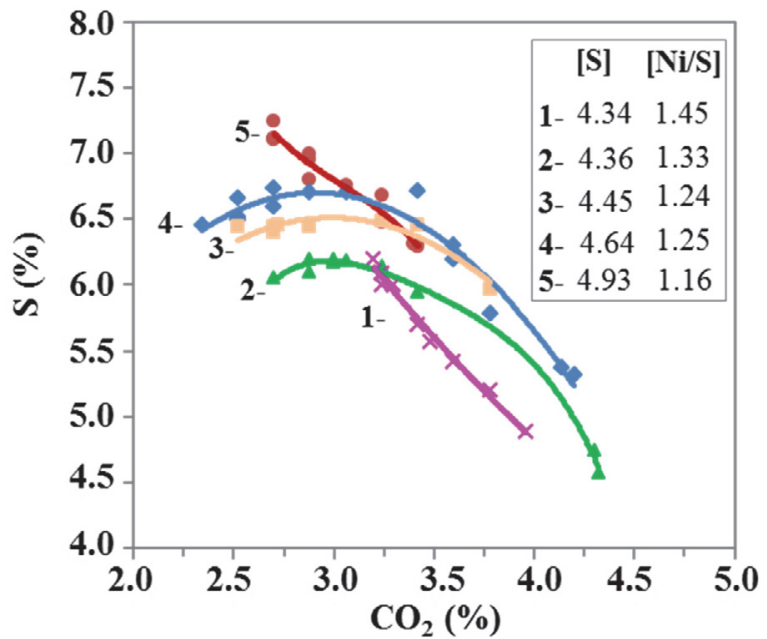

Figure 7. Interaction between sulfur and carbon dioxide in the $\mathrm{Ba}$ sic Nickel Carbonate, industrial process (Stage 03). The [S] concentration $\left(\mathrm{g} \cdot \mathrm{L}^{-1}\right)$ and the $[\mathrm{Ni} / \mathrm{S}]$ ratio in the Product-liquor can be appreciated. $1.60 \leq \mathrm{NH}_{3} / \mathrm{CO}_{2}<1.80$.

solution by a side tray of the steam-stripped column, increases the selectivity towards the carbonate formation in the BNC molecule with sulfate decreasing, which is favorable for the calcination process reducing the energy consumption.

Regarding the effect of the $\mathrm{pH}$ of the BNC suspension, the sulfur concentration decreased in the BNC molecule with the increase in the alkalinity of the suspension $(7.7 \leq \mathrm{pH} \leq 9.1)$, which suggests that the thermodynamic equilibrium of the system tend to increase the relative stability (predominance) of $\mathrm{NiCO}_{3}$ while deceases for $\mathrm{NiSO}_{4}$, although both species coexistent in the solid phase (Fig. 8 and Fig. 9). Figures 5 to 9 also suggest that under over-distillation conditions, nickel leached appreciably with a strong dependence on sulfur concentration.

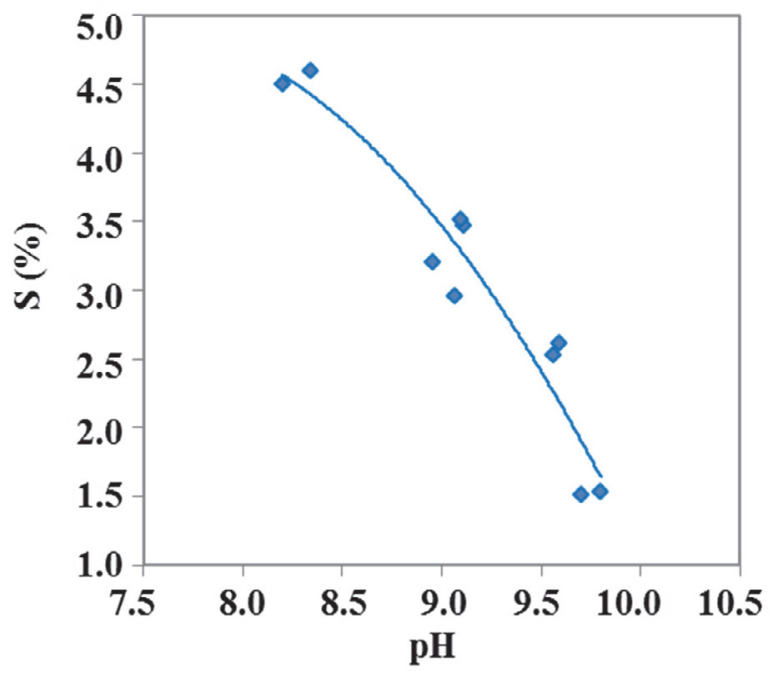

Figure 8. Interaction between sulfur contained in the BNC and $\mathrm{pH}$ suspension, mini-column (Stage 01).

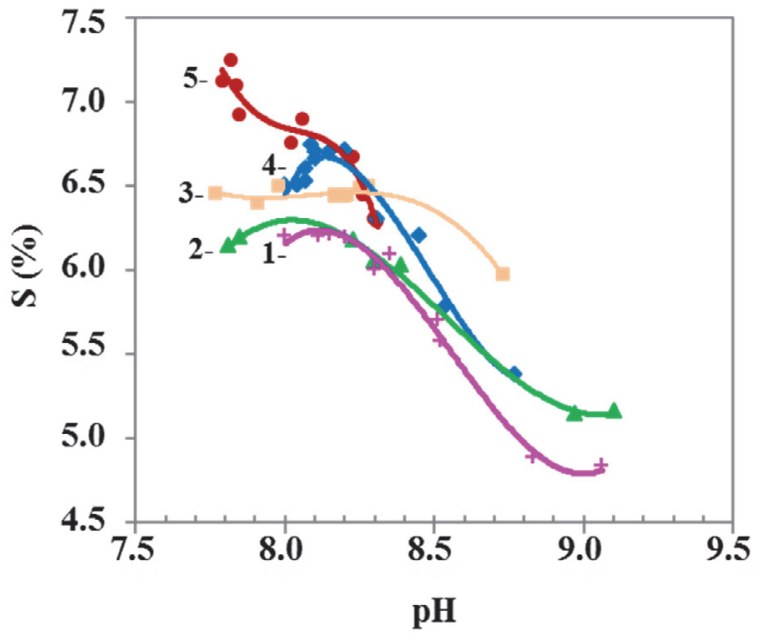

Figure 9. Interaction between sulfur contained in the $\mathrm{BNC}$ and $\mathrm{pH}$ suspension, industrial process (Stage 03). $1.60 \leq \mathrm{NH}_{3} / \mathrm{CO}_{2}<1.80$.

\section{3. Sulfur Effect on the Operating Expenses}

Operating expenses, $(G)$, were calculated for 10 dataset, and these were plotted as a $\mathrm{pH}$ function in the BNC suspension at the bottom outlet of the columns. The average values of sulfur concentration $\left(\mathrm{g} \cdot \mathrm{L}^{-1}\right)$, ratio $\mathrm{Ni} / \mathrm{S}, \mathrm{Ni} /$ $\left[\mathrm{S}_{2} \mathrm{O}_{3}{ }^{2-}\right]$ and $\mathrm{Ni} /\left[\mathrm{SO}_{4}{ }^{2-}\right]$ in the Product-liquor, were included in the graph, for the dataset that overlapped in the expense curve, in the interval $8.2 \leq \mathrm{pH} \leq 8.7$, (Fig. 10).

As shown in Figure 10, for the periods of operation characterized by carbonation according to $1.60 \leq \mathrm{NH}_{3} /$ $\mathrm{CO}_{2}<1.80$ in the Product-liquor, between $\mathrm{pH} 8.3$ and $\mathrm{pH}$ 8.7 , there were a directly proportional relationship between the expenses and dissolved-sulfur concentration, and inversely proportional to the $\mathrm{Ni} /\left[\mathrm{S}_{\mathrm{x}} \mathrm{O}_{\mathrm{y}}{ }^{\mathrm{z}}\right]$ ratio; there-

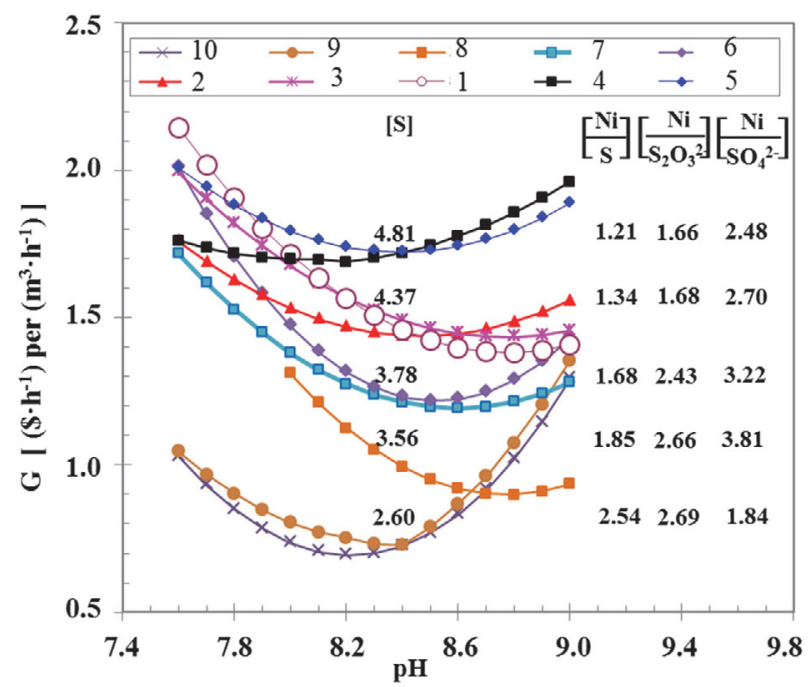

Figure 10. Operating expenses in $\mathrm{pH}$ function $\left(1.60 \leq \mathrm{NH}_{3} /\right.$ $\mathrm{CO}_{2}<1.80$ ). The $[\mathrm{S}]$ average concentration $\left(\mathrm{g} \cdot \mathrm{L}^{-1}\right),[\mathrm{Ni} / \mathrm{S}],[\mathrm{Ni} /$ $\left.\mathrm{S}_{2} \mathrm{O}_{3}{ }^{2-}\right],\left[\mathrm{Ni} / \mathrm{SO}_{4}{ }^{2-}\right]$ ratio in the Product-liquor can be appreciated (Stage 03). 
fore, at a low sulfur concentration and a high $\mathrm{Ni} /\left[\mathrm{S}_{\mathrm{x}} \mathrm{O}_{\mathrm{y}}{ }^{\mathrm{z}}\right]$ ratio, the expenses for ammonia losses and the consumption of nickel precipitation reagent decrease. This tendency was similar for carbonation corresponding to $1.80 \leq$ $\mathrm{NH}_{3} / \mathrm{CO}_{2} \leq 2.0$. The nickel cation concentration tends to increase, coordinated with $\left[\mathrm{S}_{\mathrm{x}} \mathrm{O}_{\mathrm{y}}{ }^{\mathrm{z}}\right]$ ligand, thus the operating expenses augments.

The economic benefit $(A)$ was calculated for several $\mathrm{pH}$ ranges. The greatest economic benefit of $0.125\left(\$ \cdot \mathrm{h}^{-1}\right)$ per $\left(\mathrm{m}^{3} \cdot \mathrm{h}^{-1}\right)$ of Product-liquor was obtained in the range $8.4 \leq \mathrm{pH} \leq 8.7$ (Fig. 11, curve A). The losses are represented to $A \leq 0$, consequently, the operation for $\mathrm{pH}$ doesn't produce an economic benefit due to the high operation expenses, so, should be avoided operating in $\mathrm{pH}$ ranges less than 8.0 in the BNC suspension. The curve B was estimated by increasing the price of ammonia and the precipitation reagent by $70 \%$; and the curve $\mathrm{C}$, modifying only the ammonia price by that same percent.

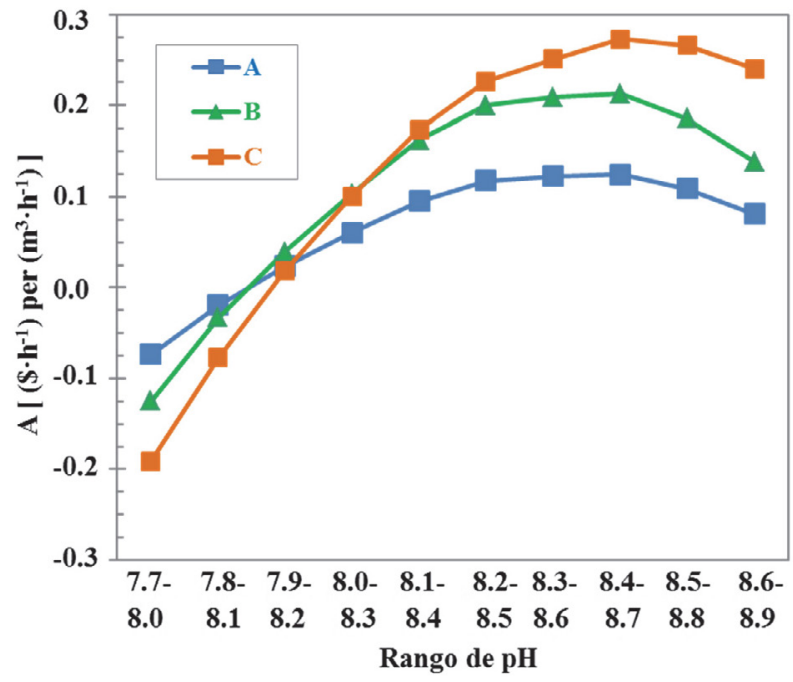

Figure 11. Interaction of suspension $\mathrm{pH}$ with the economic benefit $\left(A, \$ \cdot h^{-1}\right.$ per $\left.\mathrm{m}^{3} \cdot \mathrm{h}^{-1}\right)$, regarding ammonia losses and nickel precipitation reagent consumption.

\section{4. Nickel Leaching of BNC Molecule by Effect of Dissolved Sulfur}

The nickel leaching of the Basic Nickel Carbonate in the distillation process, occur due to the interactions between the variables ionic species concentration in the liquid medium (system $\mathrm{Ni}(\mathrm{II})-\mathrm{NH}_{3}-\mathrm{CO}_{2}-\mathrm{SO}_{2}-\mathrm{H}_{2} \mathrm{O}$ ) and the chemistry composition of the BNC molecule, which, in turn, depends on the chemical composition of the Product-liquor that is fed to the process, the thermal profile in the columns and $\mathrm{pH}$ in the $\mathrm{BNC}$ suspension.

The sulfur ions $\left[\mathrm{S}_{\mathrm{x}} \mathrm{O}_{\mathrm{y}}{ }^{\mathrm{z}}\right]$ will be present in the solution; these are formed by oxidation of the sulfur that is incorporated to the process with the petroleum. On the other hand, the equilibrium $\mathrm{NH}_{4}{ }^{+} / \mathrm{NH}_{3}$ and $\mathrm{HCO}_{3}{ }^{-} /$
$\mathrm{CO}_{3}{ }^{2-}$ depend on the suspension $\mathrm{pH}$. The following reactions are proposed: Eqs. (18)- (22): 2,21

$$
\begin{aligned}
& \mathrm{NiSO}_{4}+\mathrm{NH}_{4} \mathrm{OH}+n \mathrm{NH}_{3} \rightarrow \\
& \rightarrow \mathrm{Ni}\left(\mathrm{NH}_{3}\right)_{n+1} \mathrm{SO}_{4}+\mathrm{H}_{2} \mathrm{O} \quad(1 \leq n \leq 5) \\
& \mathrm{NiCO}_{3}+\left(\mathrm{NH}_{4}\right)_{2} \mathrm{SO}_{4}+(n+2) \mathrm{NH}_{3}+\mathrm{H}_{2} \mathrm{O} \rightarrow \\
& \rightarrow \mathrm{Ni}\left(\mathrm{NH}_{3}\right)_{4+n} \mathrm{SO}_{4}+\mathrm{CO}_{2}+2 \mathrm{H}_{2} \mathrm{O} \quad(0 \leq n \leq 2) \\
& \mathrm{Ni}(\mathrm{OH})_{2}+\left(\mathrm{NH}_{4}\right)_{2} \mathrm{SO}_{4}+n \mathrm{NH}_{3} \rightarrow \\
& \rightarrow \mathrm{Ni}\left(\mathrm{NH}_{3}\right)_{2+n} \mathrm{SO}_{4}+4 \mathrm{H}_{2} \mathrm{O} \quad(1 \leq n \leq 4) \\
& \mathrm{Ni}(\mathrm{OH})_{2}+\left(\mathrm{NH}_{4}\right)_{2} \mathrm{~S}_{2} \mathrm{O}_{3}+n \mathrm{NH}_{3} \rightarrow \\
& \rightarrow \mathrm{Ni}\left(\mathrm{NH}_{3}\right)_{2+n} \mathrm{~S}_{2} \mathrm{O}_{3}+2 \mathrm{H}_{2} \mathrm{O} \quad(1 \leq n \leq 4) \\
& \mathrm{Ni}{ }^{2+}+\mathrm{NH}_{4} \mathrm{OH}_{+}(n-1) \mathrm{NH}_{3}+\mathrm{CO}_{2}+(n-1) \mathrm{H}_{2} \mathrm{O} \rightarrow \\
& \rightarrow \mathrm{Ni}\left(\mathrm{NH}_{3}\right)_{n} \mathrm{CO}_{2}+n \mathrm{H}_{2} \mathrm{O} \quad(2 \leq n \leq 6)
\end{aligned}
$$

When the sulfur concentration increases in the Product-liquor, the selectivity towards sulfate formation in the BNC molecule increases while the carbonate formation decreases (Fig. 6 and Fig. 7); this favors the nickel leaching of the BNC molecule (Fig. 8 and Fig. 9), increases the Ni cation in solution and the operational costs (Fig. 10).

The complex compounds concentration, simulating the species ionic in the steam-stripped columns discharge, were determined at $\left[\mathrm{NH}_{3}\right] 0.01 \mathrm{M},\left[\mathrm{CO}_{3}{ }^{2-}\right] 0.1 \mathrm{M},\left[\mathrm{SO}_{4}{ }^{2-}\right]$ $0.02 \mathrm{M}$ and $\left[\mathrm{S}_{2} \mathrm{O}_{3}{ }^{2-}\right] 0.01 \mathrm{M}$. ${ }^{\mathrm{I}} \mathrm{n}$ the measure that diminishes the $\mathrm{pH}$ in the BNC suspension in the columns effluents, the nickel cation concentration tend to decreasing coordinated with $\left[\mathrm{NH}_{3}\right]$ ligand with high coordination number, but tend to increasing with $\left[\mathrm{S}_{\mathrm{x}} \mathrm{O}_{\mathrm{y}}\right]$ ligands, propitiating the nickel leaching of the BNC molecule, (Fig. 12).

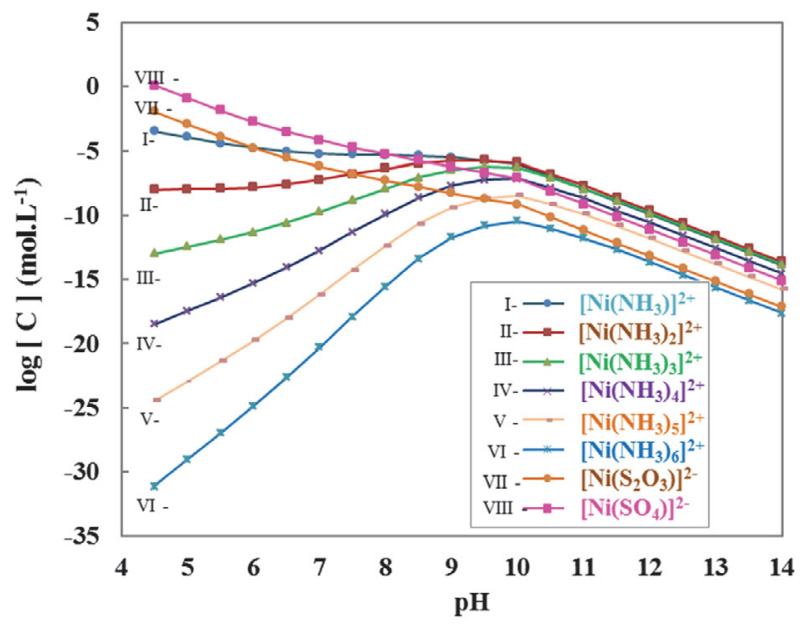

Figure 12. Log concentration of nickel complex compounds, $\left[\mathrm{NH}_{3}\right]$ $0.01 \mathrm{M},\left[\mathrm{CO}_{3}{ }^{2-}\right] 0.1 \mathrm{M},\left[\mathrm{SO}_{4}{ }^{2-}\right] 0.02 \mathrm{M},\left[\mathrm{S}_{2} \mathrm{O}_{3}{ }^{2-}\right] 0.01 \mathrm{M}$

The predominance area diagram, (Fig. 13), represent thermodynamic stability area of solid and aqueous species, in function of $\mathrm{pH}$ and $\left[\mathrm{CO}_{3}{ }^{2-}\right]$ anion concentration, under 
approximately the same conditions when the deep precipitation of BNC begin: $\mathrm{pH}<10.33, \mathrm{Ni}$ (II) $0.14 \mathrm{M},\left[\mathrm{NH}_{3}\right]$ $1.2 \mathrm{M},\left[\mathrm{SO}_{4}{ }^{2-}\right] 0.03 \mathrm{M}$ and $-0.7 \leq \log \left[\mathrm{CO}_{3}{ }^{2-}\right] \leq-0.16$. Based on this diagram, at higher carbonation of the Product-liquor, the thermodynamic stability area of $\mathrm{NiCO}_{3}$ increases, while it decreases for the $\mathrm{Ni}(\mathrm{OH})_{2}$; furthermore, it is important to control the $\mathrm{pH}$, in order to reduce the tendency to $\mathrm{NiSO}_{4}$ conversion, (Fig. 8 and Fig. 9). The experimental results have shown that when a Product-liquor is fed with low sulfur concentration, the highest $\mathrm{Ni} / \mathrm{S}$ and $\mathrm{Ni} /$ [ $\mathrm{S}_{\mathrm{x}} \mathrm{O}_{\mathrm{y}}{ }^{\mathrm{z}}$ ] ratio, $\mathrm{NH}_{3} / \mathrm{CO}_{2}<1.8$, as well as $\mathrm{CO}_{2}$-rich solution by a side trays of the columns, it is also favorable to reducing the dissolved nickel, improve the BNC composition and its chemical-physical properties, (Fig. 4).

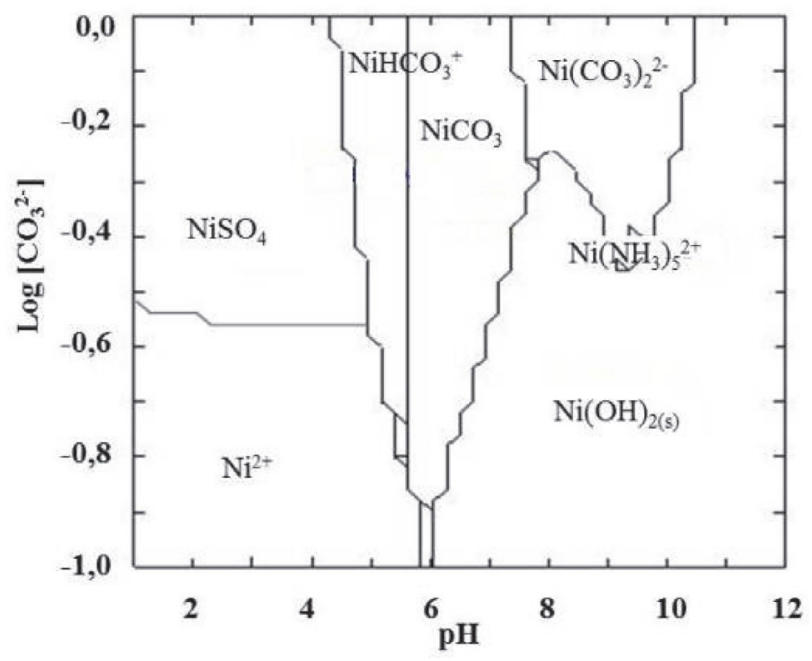

Figure 14. Predominance area diagram, $\mathrm{Ni}(\mathrm{II}) 0.14 \mathrm{M},\left[\mathrm{NH}_{3}\right] 1.2 \mathrm{M}$, $\left[\mathrm{SO}_{4}{ }^{2-}\right] 0.03 \mathrm{M}$.

Using the complementary norm for the operation control by $\mathrm{pH}(8.4 \leq \mathrm{pH} \leq 8.7)$, it is possible to adjust the thermal profile in the steam-stripped columns to reduce the nickel leaching from the $\mathrm{BNC}$ molecule and the $\left[\mathrm{Ni}^{2+}\right]$ cation in solution, which allow to reduce expenses due to ammonia losses and in the nickel chemical precipitation process; in addition, the chemical-physical properties of BNC are improved, favoring the subsequent filtration and calcination processes. It is proposed to measure the $\mathrm{pH}$ at $25^{\circ} \mathrm{C}$ in the BNC suspension at the columns outlet. If $\mathrm{pH}$ $\leq 8.4$ (over-distillation), the temperature at the top of the column should be lowered by reducing the steam flow until reaching a $\mathrm{pH}$ in the recommended range; but if $\mathrm{pH} \geq$ 8.7 (sub-distillation), the temperature should be raised by increasing the steam flow.

\section{Conclusions}

The distillation process in the Ammoniacal Carbonate Leaching technology was studied at bench-scale and industrial, in order to determine the dissolved sulfur effect in the Product-liquor that feeds to the steam-stripped columns, over the Basic Nickel Carbonate (BNC) properties and the operation expenses.

The $\mathrm{BNC}$ general structure is $\left(\mathrm{NiCO}_{3}\right)_{\mathrm{x}} \cdot\left(\mathrm{Ni}(\mathrm{OH})_{2}\right)_{\mathrm{y}}$. $\left(\mathrm{NiSO}_{4}\right)_{\mathrm{z}} \cdot \mathrm{nH}_{2} \mathrm{O}$. When increasing the sulfur concentration in the liquor, augment the selectivity towards the $\left[\mathrm{SO}_{4}{ }^{2-}\right]$ formation with diminishing of $\left[\mathrm{CO}_{3}{ }^{2-}\right]$ in the molecule; also, when decreases the alkalinity of the BNC suspension $(7.8 \leq \mathrm{pH} \leq 10,0)$ the thermodynamic stability area of $\mathrm{NiSO}_{4}$ tend to increasing, which affects the operation expenses due to the sulfur requires high energy consumption for the thermal decomposition in the calcination process.

The concentration of species ionic in the system $\mathrm{Ni}(\mathrm{II})-\mathrm{NH}_{3}-\mathrm{CO}_{2}-\mathrm{SO}_{2}-\mathrm{H}_{2} \mathrm{O}$ is dependent of $\mathrm{pH}$, when decrease the alkalinity of the suspension the nickel is leached form the $\mathrm{BNC}$, increases $\mathrm{Ni}$ (II) cation in solution because of complex reaction with $\left[\mathrm{SO}_{4}{ }^{2-}\right]$ and $\left[\mathrm{S}_{2} \mathrm{O}_{3}{ }^{2-}\right]$ ions; therefore, it goes up consumption precipitation reagent and the operation expenses.

Feeding carbonated Product-liquor in the range 1.60 $\leq \mathrm{NH}_{3} / \mathrm{CO}_{2}<1.80$ and $\mathrm{CO}_{2}$-rich solution increase the $\mathrm{CO}_{2}$ in the $\mathrm{BNC}$ with decreasing of sulfate; thus, the mean diameter particle increase, the filtration specific resistance and the cake moisture diminishes, which increase the productivity and decrease the energy consumption in the process of filtration and calcination; furthermore, keeping a $\mathrm{pH}$ between 8.4 and 8.7 in the columns outlet the greatest economic benefit is obtained of $0.125\left(\$ \cdot \mathrm{h}^{-1}\right)$ per $\left(\mathrm{m}^{3}\right.$. $\mathrm{h}^{-1}$ ) of Product-liquor.

\section{Acknowledgment}

Thanks to Maela Margarita Mariño-Pérez, Professor Associate University of Holguín; Georgina Aguilera Saborí, Professor Associate, University of Moa; Nélida Powery Ebanks, NICAROTEC Co.; and colleagues of the Chemical Analysis Laboratory, CEDINIQ, Nicaro, Cuba, for their collaboration.

\section{Conflict of Interest}

The authors declare no conflict of interest

\section{References}

1. A. R. C. Chang, A. V. Vargas, Tecnol. Quim. 2009, 29, 98-107.

2. A. V. Rojas, M. E. H. Magaña, R. A. Ricardo, Rev. Metal. (Madrid, Spain). 2019, 55, 1-11. DOI:10.3989/revmetalm.149

3. A. R. C. Chang, R. H. Molina, E. R. Vega, M. R. Ortiz. Minería y Geología, 2003, 19, 59-64.

4. Y. D. Gainza, M.E. Magaña, A. V. Rojas, C. G. Sánchez. Tecnol. Quim. 2016, 36, 407-416. DOI: 10.1590/2224-6185.2016.3.8

5. M. M. R. Romero, J. C. Y. Llópiz. Minería y Geología, 1996, 13, 61-67. 
6. M. A. Rhamdhani. Metall. Trans. B. 2008, 39B, 234-245. DOI:10.1007/s11663-008-9139-5

7. M. A. Rhamdhani. Metall. Trans. B. 2008, 39B, 218-233. DOI:10.1007/s11663-007-9124-4

8. M. E. H. Magaña, A. V. Rojas, Tecnol. Quim. 2013, 33, 200205. DOI: $10.1590 / 2224-6185.2013 .3 . \% 25 x$

9. A. V. Rojas, M. E. N. Trujillo, Tecnol. Quim. 2012, 32, 177-185. DOI:10.5482/HAMO-12-05-0003

10. X. Y. Guo, K. Huang, D. M. Zhang, Nonferr. Metal. Soc. China. 2014, 14, 1006-1011. DOI: 1003-6326(2004)05-1006-07.

11. K. Osseo-Asare, S.W. Asihene, In: Proceedings of International Laterite Symposium, New Orleans, LA, 1979, pp. 19-21.

12. D. Grujicic, B. Pesic, Electrochim Acta. 2006, 51, 2678-2690. DOI:10.1016/j.electacta.2005.08.017

13. O. Söhnel, J. Mullin, Cryst. Res. Technol. 1979, 14, 217-228. DOI:10.1002/crat.19790140215

14. J. R. O. Gutiérrez, A. V. Rojas, Tecnol. Quim. 2018, 38, 24-35. DOI: $10.1590 / 2224-6185.2018 .1 . \% 25 x$
15. S. C. Santos, O. Rodrigues, L. L. Campos. Curr. Smart Mater., 2018, 3, 3-20. DOI:10.2174/2405465802666171012143956

16. L. Pilon, H. Wang, A. d'Entremont. J. Electrochem. Soc. 2015, 162, A5158-A5178. DOI:10.1149/2.0211505jes

17. V. Tohver, J. E. Smay, A. Braem, P. V. Braun, J. A. Lewis. Proc. Natl. Acad. Sci. U.S.A. 2001, 98, 8950-8954.

DOI:10.1073/pnas.151063098

18. M. Moradi, Q. He, G. A. Willing. Colloids Surf. A. 2019, 577, 532-540. DOI:10.1016/j.colsurfa.2019.06.021

19. L. Fang, L. Na, Z. Zhao, P. Shaofang. J. Wuhan Univ. Technol. Mater. Sci. Ed. 2008, 23, 331-333.

DOI:10.1007/s11595-007-3331-3

20. C. G. Anderson, in: C. G. Anderson, R. C. Dunne, J. L. Uhrie (Ed.): Minerals Processing and Extractive Metallurgy: 100 years of innovation, Englewood, Colorado: Society for Mining, Metallurgy \& Exploration, 2014, pp. 403-426.

21. N. E. Kotelnikova, A.M., Mikhailidi. Cell. Chem. Technol. 2012, 46, 27-33.

\section{Povzetek}

V laboratorijskem in industrijskem merilu smo preučevali proces destilacije v tehnologiji amoniakalnega karbonatnega izpiranja. Ugotavljali smo vpliv žvepla v raztopini, ki jo dovajamo na kolone, na lastnosti bazičnega nikljevega karbonata in obratovalne stroške. S povečanjem vsebnosti žvepla $v$ raztopini smo izboljšali selektivnost pri tvorbi sulfata v molekuli BNC; povečala se je poraba energije pri termičnem razkroju BNC v procesu kalcinacije. Prav tako se je povečala količina niklja raztopljenega $\mathrm{v}$ raztopini na kolonah zaradi tvorbe kompleksov $\mathrm{z}$ ioni $\left[\mathrm{SO}_{4}{ }^{2-}\right]$ in $\left[\mathrm{S}_{2} \mathrm{O}_{3}{ }^{2-}\right]$, kar je zvišalo stroške povezane $\mathrm{z}$ obarjalnim reagentom. Če na kolone dovajamo raztopino z dodatkom $\mathrm{CO}_{2} \mathrm{v}$ območju $1.60 \leq \mathrm{NH}_{3} / \mathrm{CO}_{2}<$ 1.80 povečamo vsebnost $\mathrm{CO}_{2} \mathrm{v}$ BNC ob sočasnem zmanjšanju vsebnosti sulfata, povečamo povprečni premer delcev, zmanjšamo upor pri filtraciji in tako izboljšamo produktivnost in zmanjšamo porabo energije pri filtraciji in kalcinaciji. $\mathrm{Z}$ vzdrževanjem pH med 8.4 in $8.7 \mathrm{v}$ iztoku iz kolon dobimo največjo ekonomičnost procesa $0,125\left(\$ \cdot \mathrm{h}^{-1}\right) \mathrm{na}\left(\mathrm{m}^{3} \cdot \mathrm{h}^{-1}\right)$ produkta.

Except when otherwise noted, articles in this journal are published under the terms and conditions of the Creative Commons Attribution 4.0 International License 